\title{
Pengaruh Pencucian Permukaan Kaleng Minuman terhadap Keberadaan Bakteri Koliform-Fecal
}

\author{
Muhammad Asril ${ }^{1}$, R.A. Hoetary Tirta Amallia ${ }^{2}$ \\ ${ }^{1}$ Program Studi Biologi, Institut Teknologi Sumatera, Lampung, Jalan Terusan Ryacudu, Way Hui, Jati Agung, Lampung \\ Selatan, Lampung, Indonesia \\ 2 Program Studi Biologi. UIN Raden Fatah Palembang
}

Info Artikel : Diterima November 2017 ; Disetujui Februari 2018; Publikasi April 2018

\begin{abstract}
ABSTRAK
Latar belakang: Tempat dan kondisi penyimpanan produk minuman kemasan yang baik merupakan salah satu penentu adanya kualitas pada produk minuman kemasan/ kaleng. Keberadaan bakteri akibat kondisi yang tidak sesuai tidak hanya terdapat di air dalam kemasan, tetapi juga terdapat di permukaan kaleng minuman sehingga perlu ada penanganan lebih lanjut pada permukaan kaleng yang akan dikonsumsi. Tujuan dari penelitian ini untuk mengetahui pengaruh pencucian permukaan kaleng minuman terhadap keberadaan bakteri koliform-fecal pada produk minuman yang dijual dipinggir jalan.

Metode: Penelitian ini bersifat deskriptif analitik dengan desain Quasy experiment dengan rancangan one group design pre-test and post-test design. Pengujian ini menggunakan sampel air yang terdapat dipermukaan kaleng minuman dan dilakukan uji mikrobiologis menggunakan metode Most Probable Number (MPN) dengan perlakuan sebelum dan setelah dilakukan pencucian dengan air mengalir.

Hasil: Hasil uji univariat menunjukkan bahwa dari 10 sampel kaleng minuman yang diuji terdapat penurunan jumlah rata-rata angka koliform dan koliform fecal sebanyak $78 \mathrm{cfu} / \mathrm{ml}$ menjadi $7 \mathrm{cfu} / \mathrm{ml}$. Uji bivariat menunjukkan bahwa terdapat perbedaan yang signifikan terhadap keberadaan bakteri koliform $(p<0,05, p=0,02)$ dan koliform fecal $(\mathrm{p}<0,05, \mathrm{p}=0,008)$ sebelum dan setelah dilakukan pencucian.

Simpulan: Terdapat penurunan secara signifikan keberadaan bakteri koliform-fecal pada permukaan kaleng minuman yang dijual dipinggir jalan setelah dicuci dengan air mengalir sehingga mampu menurunkan resiko kontaminasi.
\end{abstract}

Kata kunci: koliform; minuman kaleng; Most Probable Number; pencucian.

\begin{abstract}
Title: The Effect of Washing the Cans Suface on the Presence of the Coliform-Fecal Bacteria

Background: The storage location and condition of good beverage packaging products is one of the determinants of the beverage packaging products/cans quality. The presence of bacteria due to unsuitable conditions is not only found in the water in packs, but also on the surface of the beverage cans so that there must be advanced treatment on the surface of the cans to be consumed. The purpose of this study is to observe the effect of washing the drink cans surface towards the presence of coliform-fecal bacteria in beverage products sold on the sidewalk.

Method: This research is analytical descriptive with Quasy experiment method (one group of pre-post test design). These tests uses water samples on the surface of the can and performed microbiological tests using the Most Probable Number (MPN) method with pre and post treatment which washing with fresh water.

Result: The result of univariate test showed from 10 samples of beverage cans tested there was a decrease of the average number of coliform -fecal counted $78 \mathrm{cfu} / \mathrm{ml}$ to $7 \mathrm{cfu} / \mathrm{ml}$. Bivariate tests showed significant differences in coliform bacterial $(p<0.05, p=0.02)$ and coliform fecal $(p<0.05, p=0.008)$ existence before and after washing.

Conclusion: Therefore, it can be concluded that there is a significant decrease in the presence of coliform-fecal bacteria on the surface of the drink can after being washed with fresh water.
\end{abstract}


Keywords: coliform; beverage cans; Most Probable Number; washing.

\section{PENDAHULUAN}

Kualitas air minum merupakan hal terpenting yang harus dipenuhi dalam kehidupan manusia, tetapi proses distribusi minuman kaleng melalui proses yang panjang dan rentan mengalami kontaminasi salah satunya koliform. ${ }^{1}$ Air yang terkontaminasi dapat menyebabkan berbagai risiko penyakit pada saluran pencernaan. $^{2}$ WHO melaporkan lebih dari 30.000 orang dan anak-anak meninggal setiap hari dikarenakan kontaminasi air, dan kebanyakan berasal dari negara berkembang. ${ }^{3}$ Salah satunya Pakistan, dari 7000 sampel air terdapat kontaminasi oleh $71 \%$ bakteri koliform dan 58\% koliform-fecal. Kontaminasi air minum menyebabkan $20-40 \%$ gejala penyakit di negara ini dan kerugian ekonomi sebesar USD 0,250,58 milyar. ${ }^{4}$ Saat ini, penggunaan minuman dalam kemasan mengalami peningkatan yang cukup signifikan sebagai alternatif kesehatan konsumsi air minum. Meskipun demikian minuman kemasan tidak lebih aman daripada air non kemasan. Berbagai penelitian melaporkan bahwa keberadaan bakteri heterotropik dan koliform berdasarkan metode penghitungan sesuai standar nasional dan internasional di dalam minuman kaleng sangat tinggi. ${ }^{5}$

Selain air dalam kemasan yang memiliki resiko terkontaminasi bakteri, wadah yang merupakan kemasan dari produk minuman tersebut juga memiliki kontribusi dalam menyebabkan penyakit. Penyimpanan dan kondisi lingkungan yang tidak sesuai mampu meningkatkan jumlah bakteri termasuk koliform di permukaan wadah minuman, salah satunya minuman kaleng. Pada umumnya penjual menyimpan minuman kaleng yang dijual di dalam wadah box ice yang diisi dengan es batu agar tetap dalam kondisi dingin. Kondisi es yang mencair dan paparan matahari rentan terjadinya kontaminasi di permukaan wadah kaleng minuman. Kebiaaan konsumen yang langsung mengkonsumsi minuman langsung dari permukaan wadah memiliki kontribusi terhadap jalan masuknya bakteri dari permuakaan wadah kaleng minuman ke dalam mulut dan saluran pencernaan. Berdasarkan fakta yang telah diuraikan di atas, penelitian ini bertujuan untuk mengetahui pengaruh pencucian permukaan kaleng minuman terhadap keberadaan bakteri koliform-fecal pada produk minuman yang dijual dipinggir jalan agar mengurangi terjadinya kontaminasi silang pada air minum kemasan. Oleh karena itu, perlu ada pengujian jumlah koliform pada permukaan kaleng minuman baik sebelum dan setelah dicuci menggunakan air mengalir.

\section{MATERI DAN METODE}

Penelitian ini bersifat deskriptif analitik dengan desain Quasy experiment dengan rancangan one group design pre test and post-test design. Penelitian ini dilakukan di sepanjang Jl. Ahamd Yani, Plaju,
Palembang dan pemeriksaan sampel untuk angka coliform dilakukan di Laboratorium Biokimia STIKES Muhammadiyah Palembang. Penelitian ini telah dilakukan pada bulan April - Juni 2016. Populasi dalam penelitian ini adalah minuman kaleng yang dijual dalam wadah box ice di kios pinggir jalan daerah Plaju, Palembang. Sedangkan sampel penelitian ini adalah bagian dari populasi yang akan diteliti. Pengambilan sampel menggunakan 2 (dua) kriteria yaitu Inklusi dan accidental sample. Adapun kriteria inklusi yaitu minuman kaleng yang disimpan dalam wadah penyimpanan es (ice box). Pengambilan sampel telah dilakukan proses perizinan dengan penjual untuk dilakukan analisis terkait penelitian ini. Teknik pengambilan sampel menggunakan accidental sample yaitu pengambilan sampel dengan cara mengambil sampel yang ada pada saat dilakukan penelitian. Variabel bebas dalam penelitian ini adalah proses pencucian kaleng minuman sebelum dikonsumsi. Sedangkan variabel terikat dalam penelitian ini adalah angka bakteri koliform pada kaleng minuman. Alat yang digunakan dalam penelitian ini adalah autoclave, oven, tabung reaksi, rak tabung, cawan petri, propipet, pipet serologi, tabung durham, gelas ukur $1 \mathrm{~L}$, aluminium foil. Sedangkan bahan yang digunakan adalah Mac Conkey Agar, Brilliant Green Lactose Bile Broth (BGLBB), Lactose Broth Single Strand (LBSS), Lactose Broth Double Strand (LBDS).

Prosedur kerja dalam penelitian ini berupa sampel berupa minuman kaleng di swab menggunakan cooton swab lalu dicampurkan dengan $50 \mathrm{ml}$ aquadest untuk memenuhi jumlah inokulan yang akan diuji, dilakukan 3 kali pengulangan. Campuran aquadest dan hasil swab (inokulan) dilakukan pengujian Most Probable Number (MPN). Botol kaleng minuman selanjutnya dicuci dengan menggunakan air mengalir yang bertujuan untuk menyesuaikan kondisi di lingkungan sehari-hari. Botol kaleng minuman yang telah dicuci lalu dilakukan swab kembali seperti sebelum dicuci dan dilanjutkan dengan pengujian MPN kembali. Metode MPN melalui 3 tahapan yaitu uji pendugaan (presumptive test), uji penegasan (confirmed test) dan uji lengkap (completed test).

Uji pendugaan dilakukan dengan cara disiapkan 9 tabung reaksi yang di dalamnya yang telah dimasukkan tabung durham. 3 tabung reaksi berisi media LBDS (Lactose Broth Double Strand), 6 tabung reaksi berisi media LBSS (Lactose Broth Single Strand). Dimasukkan sebanyak $10 \mathrm{ml}$ sampel uji ke dalam 3 tabung yang berisi media LBDS. Dimasukkan sebanyak $1 \mathrm{ml}$ sampel uji ke dalam 3 tabung yang berisi media LBSS dan $0,1 \mathrm{ml}$ sampel uji ke dalam 3 tabung yang berisi media LBSS. Diinkubasi seluruh tabung selama 24 jam pada suhu $35{ }^{\circ} \mathrm{C}$. Diamati gelembung gas yang terbentuk pada tabung durham 
disetiap tabung reaksi. Dihitung nilai MPN koliform melalui tabel indeks MPN. Uji Penegasan dilakukan dengan cara disiapkan tabung reaksi yang berisi media BGLBB (Brilliant Green Lactose Bile Broth) yang di dalamnya telah terdapat tabung durham. Jumlah tabung yang digunakan disesuaikan dengan jumlah tabung yang menunjukkan uji positif pada uji sebelumnya. Dicelupkan satu ose pada tabung yang menunjukkan uji positif, kemudian dicelupkan ose tersebut ke dalam tabung yang berisi media BGLBB. Diinkubasi selama 24 jam pada suhu $35{ }^{\circ} \mathrm{C}$. Diamati gelembung gas yang terbentuk pada tabung durham disetiap tabung reaksi. Dihitung nilai MPN koliform melalui table indeks MPN. Uji lengkap dilakukan dengan cara disiapkan tabung reaksi yang telah berisi media Mac Conkey Agar masih dalam keadaan cair. Dipipet $1 \mathrm{ml}$ kultur bakteri dari media BGLBB yang menunjukkan uji positif pada uji sebelumnya lalu dimasukkan ke dalam tabung reaksi. Tabung yang berisi media dan kultur dihomogenkan, lalu dituang ke dalam cawan petri. Diinkubasi selama 24 jam pada suhu $35{ }^{0} \mathrm{C}$, dilihat koloni bakteri yang terbentuk (koloni berwarna merah menunjukkan kelompok Enterobacteriacea salah satunya Escherichia coli).

Analisis data meliputi uji normalitas dengan Saphiro wilk ( $\mathrm{p}>0,05)$, uji homogenitas varians uji homogenitas varians (Levene's Test) $(\mathrm{p}>0,05)$, uji tberpasangan dilakukan untuk mengetahui perbedaan jumlah koliform sebelum dan sesudah perlakuan dicuci dilakukan uji t-berpasangan apabila data terdistribusi normal.

\section{HASIL DAN PEMBAHASAN}

Dari hasil penelitian diketahui ada penurunan angka koliform dan koliform fecal yang signifikan. Dari 10 sampel kaleng minuman yang dijual sepanjang jalan Ahmad Yani, Palembang sebelum dicuci rata-rata angka koliform dan koliform-fecal sebanyak $78 \mathrm{cfu} / \mathrm{ml}$ dan setelah dicuci mengalami penurunan menjadi $7 \mathrm{cfu} / \mathrm{ml}$ (tabel 1). Koliform-fecal yang telah dihitung selanjutnya dilakukan pengujian lengkap dengan menggunakan media Mac Conkey Agar untuk mengetahui kelompok bakteri yang terdapat pada hasil pengujian sebelumnya. Hasil positif ditunjukkan pada semua sampel yang sebelum diberikan perlakuan berupa tumbuhnya koloni bakteri berwarna merah yang mengindikasikan jenis bakteri kelompok Enterobacteriaceae salah satunya E. coli yang merupakan jenis bakteri yang mampu menfermentasikan laktosa yang tidak boleh ada didalam sampel makanan dan minuman (patogen). Sedangkan setelah diberi perlakuan dengan pencucian sampel 3,6,7 dan 10 menunjukkan hasil negatif terhadap keberadaan kelompok Enterobacteriaceae salah satunya E.coli.

Tabel 1. Hasil Pengujian Sampel Berdasarkan Metode Most Probable Number (MPN).

\begin{tabular}{ccccccc}
\hline & \multicolumn{2}{c}{$\begin{array}{c}\text { Jumlah } \\
\text { Koliform } \\
\text { (cfu/ml) }\end{array}$} & \multicolumn{2}{c}{$\begin{array}{c}\text { Jumlah } \\
\text { Koliform Fecal } \\
\text { (cfu/ml) }\end{array}$} & \multicolumn{2}{c}{$\begin{array}{c}\text { Konfirmasi } \\
\text { Enterobacteriacea }\end{array}$} \\
\cline { 2 - 7 } & $\begin{array}{c}\text { Sebelum } \\
\text { Dicuci }\end{array}$ & $\begin{array}{c}\text { Setelah } \\
\text { Dicuci }\end{array}$ & $\begin{array}{c}\text { Sebelum } \\
\text { Dicuci }\end{array}$ & $\begin{array}{c}\text { Setelah } \\
\text { Dicuci }\end{array}$ & $\begin{array}{c}\text { Sebelum } \\
\text { Dicuci }\end{array}$ & $\begin{array}{c}\text { Setelah } \\
\text { Dicuci }\end{array}$ \\
\hline 1 & 150 & 11 & 150 & 11 & + & + \\
2 & 150 & 11 & 150 & 11 & + & + \\
3 & 4 & 0 & 4 & 0 & + & - \\
4 & 120 & 11 & 120 & 4 & + & + \\
5 & 150 & 20 & 150 & 11 & + & + \\
6 & 15 & 0 & 15 & 0 & + & - \\
7 & 21 & 0 & 21 & 0 & + & - \\
8 & 75 & 4 & 75 & 4 & + & + \\
9 & 75 & 15 & 75 & 15 & + & + \\
10 & 23 & 0 & 23 & 0 & + & - \\
\hline Jumlah & 783 & 72 & 783 & 72 & 10 & 6 \\
\hline Rata- & 78,3 & 7,2 & 78,3 & 7,2 & - & - \\
rata & & & & & &
\end{tabular}

Tabel 2. Uji Normalitas Data Jumlah Koliform

\begin{tabular}{cccc}
\hline Perlakuan & Std & Mean & p \\
\hline Jumlah koliform sebelum dicuci & 60,601 & 78,30 & 0,190 \\
Jumlah koliform sesudah dicuci & 7,34 & 7,20 & 0,120 \\
\hline
\end{tabular}

Ket: Uji normalitas dengan kolmogorov-smirnov dan Shapiro wilk $\alpha>0,05$

Hasil pengukuran jumlah koliform sebelum dicuci dibandingkan dengan jumlah koliform sesudah dicuci dengan uji t-berpasangan $(\mathrm{p}<0,05)$. Hasilnya menunjukkan nilai probabilitas $<0,05(\mathrm{p}=0,02)$, maka diambil kesimpulan bahwa terdapat perbedaan yang bermakna antara jumlah koliform sebelum dicuci 
dengan jumlah koliform setelah dicuci (tabel 3). Jumlah koliform tertinggi diperoleh pada sampel 1,2 dan 3 dengan total jumlah koliform $150 \mathrm{cfu} / \mathrm{ml}$. Sedangkan jumlah terendah diperoleh pada sampel 2 berjumlah $4 \mathrm{cfu} / \mathrm{ml}$. Setelah dilakukan perlakuan berupa pencucian jumlah koliform pada permukaan kaleng 1,2 dan 3 mengalami penurunan yang signifikan yaitu $11 \mathrm{cfu} / \mathrm{ml}$ atau mengalami penurunan sebesar 93\%. Sedangkan jumlah koliform tidak ditemukan lagi pada sampel 2.

Tabel 3. Perbandingan Jumlah Koliform Sebelum Dan Setelah Dicuci

\begin{tabular}{cccc}
\hline Perlakuan & Std & Mean & p \\
\hline Jumlah koliform sebelum dicuci & 60,61 & 78,30 & \multirow{2}{*}{0,03} \\
Jumlah koliform sesudah dicuci & 7,34 & 7,20 & \\
\hline
\end{tabular}

Ket : Uji T Berpasangan $<0,05$

Uji normalitas data jumlah koliform fecal menunjukkan data berdistribusi normal (tabel 4). Hasil menunjukkan nilai probabilitas jumlah koliform fecal sebelum dan sesudah dicuci lebih besar dari 0,05, maka diambil kesimpulan bahwa data berdistribusi normal sehingga dapat dilakukan uji t berpasangan. Hasil Pengukuran jumlah koliform-fecal sebelum dicuci dibandingkan dengan jumlah koliform sesudah dicuci dengan uji t berpasangan $(\mathrm{p}<0,05)$. Hasilnya menunjukkan nilai probabilitas $<0,05(\mathrm{p}=0,008)$, maka diambil kesimpulan terdapat perbedaan yang bermakna antara jumlah koliform-fecal sebelum dicuci sebelum dengan jumlah koliform fecal setelah dicuci (tabel 5).

Tabel 4. Uji Normalitas Data Jumlah Koliform Fecal

\begin{tabular}{lrrc}
\hline \multicolumn{1}{c}{ Perlakuan } & Std & Mean & p \\
\hline Jumlah koliform fecal sebelum dicuci & 60,601 & 78,30 & 0,190 \\
Jumlah koliform fecal sesudah dicuci & 5,835 & 5,60 & 0,138 \\
\hline Ket : Uji normalitas dengan Kolmogorov-smirnov dan Shapiro wilk $\alpha>0.05$
\end{tabular}

Tabel 5. Perbandingan Jumlah Koliform Fecal sebelum dan setelah dicuci

\begin{tabular}{cccc}
\hline Perlakuan & Std & Mean & p \\
\hline Jumlah koliform fecal sebelum dicuci & 60,601 & 78,30 & \multirow{2}{*}{0,003} \\
Jumlah koliform fecal sesudah dicuci & 5,835 & 5,60 & \\
\hline
\end{tabular}

Ket: Uji T Berpasangan $<0.05$

Dari hasil penelitian diketahui bahwa terdapat total koliform, koliform fecal yang sangat tinggi di permukaan kaleng minuman. Hal ini dapat terjadi dikarenakan cara penyimpanan kaleng minuman tersebut didalam box ice dengan menggunakan es batu sehingga diasumsikan bahwa koliform pada kaleng minuman tersebut berasal dari es batu yang mencair dan merendam permukaan kaleng minuman tersebut. Selain itu kebersihan box ice yang tidak bersih juga ikut memberikan kontribusi terhadap keberadaan koliform di permukaan kaleng. Berbagai penelitian melaporkan bahwa penyimpanan produk pada tempat dan suhu yang baik dalam periode tertentu menunjukkan bahwa tidak adanya jumlah total koliform, koliform-fecal dan E.coli pada minuman kemasan botol plastik. ${ }^{\mathbf{6 , 7 , 8}}$ Tidak ditemukannya bakteri pada makanan dan minuman merupakan indikasi bahwa makanan dan minuman tersebut layak dikonsumsi. Keberadaan bakteri di minuman kemasan plastik dan minuman kemasan sachet disebabkan oleh penanganan yang higienis oleh industri. Termasuk penggunaan tutup yang aman sehingga meningkatkan kebersihan pada produk. Hal ini sejalan dengan hasil yang diperoleh bahwa perbedaan total angka koliform dan koliform-fecal yang signifikan pada permukaan kaleng minuman sebelum dan setelah dilakukan pencucian pada air mengalir serta setelah uji statistik menunjukkan terdapat hubungan antara angka koliform, koliform-fecal dengan pencucian permukaan kaleng. Jumlah total koliform dan koliform-fecal mengalami penurunan yang signifikan setelah dilakukan perlakuan pencucian, yang menegaskan bahwa adanya bakteri dipermukaan kaleng dikarenakan air yang berasal dari box ice menempel di permukaan kaleng minuman.

Keberadaan bakteri koliform dan koliform-fecal yang tinggi di permukaan kaleng minuman cukup mengkhawatirkan, hal ini disebabkan karena kebiasaan konsumen mengkonsumsi langsung minuman kaleng dari box pendingin dan tanpa menggunakan alat bantu berupa sedotan. Kebiasaan ini dikhawatirkan menjadi jalan masuknya bakteri koliform-fecal ke dalam tubuh manusia. Bakteri koliform merupakan mikroorganisme indikator adanya 
kontaminasi mikroba di air. Akan tetapi, patogenitas tidak selamanya disebabkan oleh bakteri koliform, tetapi dengan adanya bakteri koliform kita dapat memprediksi keberadaan bakteri lain yang menyebabkan penyakit. $^{9}$ Berbagai laporan menegaskan bahwa selain Enterobacteriaceae juga terdapat jenis-jenis bakteri didalam minuman botol seperti Undibacterium spp. Mycobacterium spp., Novosphingobium spp.. ${ }^{10}$ Pengujian koliform merupakan standar pengujian yang digunakan untuk mengamati kualitas air dikarenakan prosedur pengerjaan yang gampang, biaya murah dan kemampuan memprediksi keberadaan bakteri yang cukup akurat. ${ }^{11}$

Makanan atau minuman yang akan dikonsumsi perlu diperhatikan dari segi keamanannya. Kualitas mikrobiologi merupakan standar awal dalam menganalisis keamanan produk. Eschericia coli menjadi standar keberadaan mikroba lain dalam makanan. Kontak makanan dengan pekerja atau tangan lain merupakan awal kontaminasi pada produk makanan. Permasalahannya muncul adalah jika konsumen yang mengkonsumsi makanan yang terkontaminasi memiliki imun yang rendah sehingga perlu adanya pengamanan produk dari patogen makanan. ${ }^{\mathbf{1 2}}$

Penanganan makanan dan minuman merupakan dasar dan memantau keamanan produk dan peralatan. Pengetahuan terhadap penanganan pangan seperti pelatihan, kontak makanan dengan manusia, peralatan makan hingga kebiasaan mencuci tangan atau produk sebelum dikonsumsi. Pengetahuan seperti desinfeksi ini mampu menurunkan jumlah total koliform dan Enterobacteriaceae. Pemahaman masyarakat tentang kebersihan minuman yang akan diminum itu merupakan dasar penurunan kontaminasi silang pada produk pangan (minuman).$^{\mathbf{1 3}}$ Berbagai laporan terkait hal ini menunjukkan bahwa penurunan jumlah bakteri sangat signifikan. Keberhasilan dalam standar mikrobiologi ini berasosisi dengan pemahaman masyarakat tentang penanganan produk pangan yang baik. ${ }^{14}$

Sebenarnya peran penelitian ini dikarenakan konsumen yang lebih memilih produk botol kemasan dan $77 \%$ konsumen menganggap membeli minuman botol lebih sehat dibandingkan dengan yang lain dan $73 \%$ mengatakan lebih nyaman. ${ }^{\mathbf{1 5}}$ Oleh karena itu, kewaspadaan konsumen terhadap penyimpanan dan kebersihan permukaan kaleng sangat rendah, padahal tempat penyimpanan tersebut merupakan bagian penting penyebab terjadinya kontaminasi silang produk minuman sehingga mampu menyebabkan berbagai resiko penyakit gastrointestinal yang seharusnya tidak terjadi.

\section{SIMPULAN}

Terdapat penurunan jumlah bakteri koliform dan koliform-fecal setelah dilakukan pencucian pada permukaan kaleng minuman. Jumlah terendah bakteri baik koliform maupun koliform-fecal sebelum dilakukan pencucian dengan air mengalir adalah 4 $\mathrm{cfu} / \mathrm{ml}$ dan tertinggi sebesar $150 \mathrm{cfu} / \mathrm{ml}$ dengan ratarata $78 \mathrm{cfu} / \mathrm{ml}$. Ada pengaruh pencucian terhadap penurunan jumlah koliform dan koliform fecal pada permukaan kaleng minuman. Penurunan jumlah bakteri baik koliform maupun koliform-fecal sebesar 93\%. Sebaiknya pada penelitian selanjutnya dilakukan analisis lama proses penyimpanan dalam box ice dengan jumlah kontaminasi koliform dan bakteri patogen lainnya pada kaleng minuman. Saran bagi konsumen yang mengonsumsi minuman kaleng yang dijual di pinggir jalan agar dapat mencuci permukaan kaleng dengan air mengalir atau menggunakan sedotan sebelum mengkonsumsi minuman kaleng.

\section{UCAPAN TERIMA KASIH}

Terima kasih penulis ucapkan kepada STIKES Muhammadiyah Palembang atas pendanaan penelitian ini melalui Hibah STIKES Muhammadiyah Palembang kepada Muhammad Asril, M.Si dan pedagang minuman pinggir jalan di Jalan Ahmad Yani, Palembang yang telah membantu terlaksananya penelitian ini.

\section{DAFTAR PUSTAKA}

1. Pant, N.D., Poudyal N. \& Bhattacharya S.K. Bacteriogical quality of bottled drinking water versus municipal tap water in Dharm municipality, Nepal. Journal of Health, Population and Nutrition. 2016; 35(17): 1-6.

2. Akoto $\mathrm{O}$ and Adiyah J. Chemical analysis of drinking water from some communities in the Brong Ahafo region. International Journal Environ Sci Tech. 2007; 4(2): 211-214.

3. World health Organization. Guidelines for drinking water quality. $4^{\text {th }}$ ed. Geneva: WHO; 2011.

4. Nabeela, F.,Azizullah, A.,Bibi, R.,Uzma, S., Murad,W., Shakir, S.K.,Ullah, W., Qosim, M. \& Hader D.P. Microbial contamination of drinking water in Pakistan-a review. Environ Sci Pollut Res. 2014; 21(24):13929-13942.

5. Semerjian LA. Quality assessment of various bottled waters marketed in Lebanon. Environ Monit Asses. 2011;172(1-4): 274-285.

6. Akinde, S.B.,Michael, I.N. \& Adindu, S.O. Storage effect of quality of sachet water produced within port Harcourt Metropolis. Jordan Journal of Biological Sciences. 2011; 4:157-164.

7. Atuanya, E.I., Seidu, R.I. \& Orjiakor, P.I. Effect of storage/biofilm formation on physiochemical and bacteriological qualities of potable water supply in Benin city. Nigeria Society for Experimental Journal. 2014;14(3): 59-66.

8. Atuanya, E. I., Adeghe, O.M. \& Udochukwu, U. Bioavailability of Plastic Contaminants and Their Effect on Plastic Bottled and Sachet Drinking Water Supplies. British Microbiology Research Journal. 2016;14(4):1-10. 
9. Emmanuel, E., Pierre, M.G.,Perrodin, Y. Groundwater contamination by microbiological and chemical substances released from hospital wastewater and health risk assessment for drinking water. BMC Public Health. 2009; 9:476.

10. Franca, L., Lopez-lopez, A.,Rossello-Mora, R. \& da Costa, M.S. Microbial diversity and dynamics of a groundwater a still bottled natural mineral water. Environmental Microbiology. 2015; 17(3):577-593.

11. Odonkor, S.T \& Ampofo, J.A. Eschericia coli as an indicator of bacteriological quality of water: an overview. Microbial Research: 2013;4(2): 511 .

12. Marzano, Maria Ada., \& Balzaretti, C.M. Protecting child health by preventing schoolrelated foodborne illnesses: Microbiological risk assessment of hygiene practices, drinking water and ready-to-eat foods in Italian kindergartens and schools. Food control. 2013;34(2): 560-567

13. Soares, K.,Garcia-Diez, J.,Esteves, A.,Oliveira, I., \& Saraiva C. Evaluation of food safety training on hygienic conditions in food establishments. Food Control: 2013;34(2): 613618

14. Castleden, H., Crooks, V.A., \& Meerveld, I.V. Examining the public health implications of drinking water-related behaviours and perceptions: A face-to-face exploratory survey of residents in eight coastal communities in British Columbia and Nova Scotia. The Canadian Geographer. 2015;59(2): 111-125.

15. Collins, H. \& Wright A. Still sparkling: The phenomenon of Bottled Water-An irish context. Journal of Marketing Management: 2014: 2(1): 15-31. 